\title{
Sistem Pendukung Keputusan Pemilihan Kepala Biro Menggunakan Metode Simple Additive Weighting (SAW)
}

\author{
Hamidah $^{[1]^{*}}$, Okkita Rizan ${ }^{[2]}$, Delpiah Wahyuningsih ${ }^{[3]}$, Laurentinus ${ }^{[4]}$ \\ Sistem Informasi ${ }^{[1,2],}$, Teknik Informatika ${ }^{[3,4]}$,Fakultas Teknologi Informasi, ISB Atma Luhur \\ Jln. Jend Sudirman Kel. Selindung, Kec. Gabek, Kota Pangkalpinang \\ Pangkalpinang, Indonesia \\ hamidah@atmaluhur.ac.id ${ }^{[1],}$ orizan@atmaluhur.ac.id ${ }^{[2],}$ delphibabel@ atmaluhur.ac.id $^{[3]}$ \\ laurentinus@atmaluhur.ac.id ${ }^{[4]}$
}

\begin{abstract}
Abstrak - Biro merupakan bagian dari sebuah instansi baik pemerintah maupun swasta yang mengurus suatu pekerjaan. Setiap instansi pemerintah maupun swasta mempunyai beberapa biro. Masing-masing biro akan menangani pekerjaan yang berbeda-beda. Setiap biro dipimpin oleh seorang kepala biro dengan beberapa staf dibawahnya sehingga keberhasilan suatu biro menjadi tanggung jawab kepala biro. Untuk itu, permasalahan yang sering terjadi baik pada instansi pemerintah maupun swasta adalah masih kesulitan menentukan kepala biro yang layak menjabat amanah tersebut. Dengan banyaknya sumber daya manusia pada suatu instansi, maka instansi akan kesulitan memilih kepala biro. Untuk mengatasi permasalahan diatas, maka kami berusaha membantu pihak instansi dalam mengambil keputusan secara tepat dan cepat dengan cara menyiapkan sistem pendukung keputusan sehingga dapat membantu pihak instansi. Metode yang digunakan dalam penelitian ini adalah metode $S A W$ (Simple Additive Weighting). Berdasarkan Hasil penelitian, maka diperoleh skor 0,975 oleh kandidat V4, skor 0,925 oleh kandidat V1, skor 0,8625 oleh kandidat V2 dan skor 0,8375 oleh kandidat V3 sehingga yang terpilih menjadi kepala biro adalah kandidat yang memperoleh skor tertinggi yaitu V4.
\end{abstract}

\section{Keywords - Simple Additive Weighting, Biro, Kriteria}

Abstrak-Bureau is part of an agency, both government and private, that takes care of a job. Every government and the private agency have several bureaus. Each bureau will handle a different job. Each bureau is led by a bureau chief with several staff under him so that the success of a bureau is the responsibility of the bureau chief. For this reason, the problem that often occurs in both government and private institutions is that it is still difficult to determine the appropriate bureau head to serve in the mandate. With so many human resources in an agency, it will be difficult for the agency to choose a bureau head. To overcome the above problems, we are trying to help the agency in making decisions appropriately and quickly by setting up a decision support system so that it can help the agency. The method used in this study is the SAW (Simple Additive Weighting) method. Based on the results of the study, a score of 0.975 by candidate $V 4$ was obtained, a score of 0.925 by candidate V1, a score of 0.8625 by candidate V2 and a score of 0.8375 by candidate V3 so that the candidate who was selected to become the head of the bureau was the candidate who obtained the highest score, namely V4.

Kata Kunci-Simple Additive Weighting, Offices, Criteria

\section{INTRODUCTION}

Salah satu komponen dalam instansi yang sangat penting adalah Sumber Daya Manusia (SDM). Pengelolaan SDM pada instansi menjadi aspek dalam menentukan keberhasilan kerja pada instansi tersebut. Apabila SDM baik, maka otomatis bagian akan baik pula. Biro atau yang sering disebut bagian. Biro merupakan bagian yang mengurus suatu pekerjaan teknis penyelenggaraan sistem di instansi. Setiap biro akan dipimpin oleh seorang kepala biro. Keberhasilan setiap Biro menjadi tanggung jawab setiap kepala biro. Semua pekerjaan akan dimonitor langsung oleh kepala biro sehingga kepala biro dan staf harus mampu bekerjasama dalam menyelesaikan semua pekerjaan. Dengan adanya komunikasi yang baik, maka akan menciptakan suasana bagian akan lebih harmonis dan terkendali. Untuk itu, diperlukan kepala biro yang supel dan mampu merangkul, mengayomi serta mengawasi para stafnya.

Sumber daya manusia merupakan salah satu faktor penunjang untuk meningkatkan produktivitas kinerja suatu instansi. Oleh karena itu, sumber daya manusia yang berkompetensi tinggi akan mendukung kinerja yang akan menentukan prestasi yang dicapai setiap bagian. Hal ini dapat menjadi pertimbangan instansi dalam menentukan kepala biro setiap bagian.

Adapun penelitian ini menggunakan metode SAW (Simple Additive Weighting). Simple Additive Weighting (SAW) adalah salah satu Metode Fuzzy Multiple Attribute Decision Making (FMADM) yang mampu menyelesaikan masalah multiple attribute decision making dengan cara membobotkan semua kriteria dan alternatif yang menghasilkan nilai referensi yang tepat[1]. Kemudian dilanjutkan dengan proses perankingan yang akan menyeleksi alternatif terbaik dari sejumlah alternatif, dalam hal ini alternatif yang dimaksud adalah yang berhak diterima sebagai kepala biro baru berdasarkan kriteria-kriteria 
yang ditentukan. Dengan proses perangkingan tersebut, diharapkan penilaian akan lebih tepat karena didasarkan pada nilai kriteria dan bobot yang sudah ditentukan sehingga akan mendapatkan hasil yang lebih akurat terhadap siapa yang akan diterima menjadi kepala biro baru di suatu perusahaan

Dalam mencapai hal tersebut diperlukan Sistem Pendukung Keputusan atau Decision Support System (DSS). DSS menyediakan fasilitas untuk melakukan analisis sehingga proses pengambilan keputusan yang dilakukan oleh pelaku bisnis bisa menjadi lebih berkualitas. Analisis tersebut didasarkan pada keadaan bisnis yang sedang berjalan yang digabungkan dengan data-data dari luar perusahaan dan data privat dari pendukung keputusan [2].

Dalam pemilihan kepala biro, perusahaan harus mencari calon kepala bagian yang berkualitas dan memiliki komitmen yang tinggi dengan mempunyai kriteria-kriteria yang telah ditentukan supaya tercapainya tujuan yang diinginkan oleh perusahaan.

Penelitian ini mempunyai tujuan untuk menyelesaikan permasalahan diatas dengan cara menyiapkan sistem pendukung keputusan yang baik agar pimpinan dapat segera mengambil keputusan secara cepat. Untuk itu, kami berniat akan membantu berbagai macam pihak khususnya top management dalam pengambilan keputusan sehingga kegiatan biro pada instansi akan dapat berjalan dengan lancar tanpa hambatan apapun. Diharapkan sistem pendukung ini nanti akan dapat bekerja dengan baik sehingga dapat menjadi salah satu solusi dalam pengambilan keputusan.

\section{LITERATUR REVIEW}

Penelitian ini akan mengacu pada berbagai referensi baik dari artikel jurnal nasional, prosiding nasional, buku maupun prosiding internasional. Adapun referensi yang diambil dapat dilihat dibawah ini :

Penelitian yang dilakukan oleh sumarno dkk yang berjudul "Sistem Pendukung Keputusan dalam Menentukan Pemilihan Posisi Kepala Unit (Kanit) PPA dengan Metode Weight Product" menjelaskan bahwa hasil penelitian dengan skor tertinggi 0,314 dengan nama sample B. Adapun kriteria yang diambil kepemimpinan, paham UU, kesatuan, kepedulian, sikap, tanggungjawab, pangkat serta wawasan. Hasil penelitian tersebut sudah dapat memberikan keluaran berupa kepala kanit PPA yang terpilih sebagai rekomendasi[3]. Pada penelitian ini menggunakan metode SAW dalam pemilihan kepala biro dengan kriteria tanggungjawab, pendidikan terakhir, jenjang kepangkatan, kedisiplinan, komunikasi dan masa kerja.

Penelitian dilakukan oleh Hamidah dkk, yang berjudul "Penerapan Metode SAW (Simple Additive Weighting) dalam pemilihan dosen favorit berbasis web" menjelaskan bahwa hasil penelitian dengan nilai 17 diperoleh oleh sample V1 sebagai nilai tertinggi dan nilai 13,01 diperoleh sample V2 sebagai nilai terendah. Penelitian ini menggunakan beberapa kriteria yaitu penilaian mahasiswa, JJA, penelitian, PKM, dan disiplin[4]. Pada penelitian ini menggunakan kriteria tanggungjawab, pendidikan terakhir, jenjang kepangkatan, kedisiplinan, komunikasi dan masa kerja

Penelitian yang dilakukan oleh Shinta Siti Sundari dkk dengan judul "Sistem Pendukung Keputusan Penerimaan
Pegawai Baru Menggunakan Metode Simple Additive Weighting $(S A W)$ " menjelaskan bahwa Nilai terbesar ada pada V1 sehingga alternatif A1 (Pelamar Pertama) adalah alternatif yang terpilih sebagai alternatif terbaik dan nilai terkecil pada V2 alternatif A2 sebagai pelamar kedua yang tidak terpilih dalam penerimaan pegawai baru[5]. Pada penelitian ini ditambahkan kriteria kedisiplinan dan jenjang kepangkatan.

Penelitian oleh Rafdani dkk dengan judul Sistem Pendukung Keputusan Seleksi Pemilihan Kepala Bagian Perum Damri Surabaya" menjelaskan bahwa dalam pemilihan kepala bagian menggunakan metode MFEP dengan kriteria yang digunakan yaitu kedisiplinan, keaktifan, masa kerja, prestasi dan pendidikan dan kandidat yang diambil ada 4 orang. Dari hasil perhitungan lengkap proses Mfep, maka didapatkan hasil akhir dengan skor 10 sebagai alternatif mandor terbaik dan hasil akhir dengan skor 7,1 sebagai alternatif mandor dengan nilai terendah. kesimpulannya yang terpilih sebagai mandor adalah alternatif dengan nilai tertinggi[6]. Pada penelitian ini menggunakan metode SAW dengan mengambil 6 kriteria.

Penelitian yang dilakukan oleh Yasni dkk dengan judul "Sistem Pendukung Keputusan Penerimaan Pegawai Baru PT. PLN (Persero) Kantor Pusat Menggunakan Metode Simple Additive Weighting ( $S A W)$ yang menjelaskan bahwa penelitian ini menggunakan sistem pendukung cision model Multiple Attribute Decision Making (MADM) dengan metode Simple Additive Weighting (SAW) dengan kriteria Disiplin (C1), Masa pengalaman informal/formal (C2), Ketaatan dalam melaksanakan tugas ( C3), Keterampilan (C4), Kepemimpinan (C5), Keterampilan (C6), diperoleh (C7), Moral dan perilaku (C8), Kerjasama (C9), Kreativitas dan inovasi (C10). Berdasarkan hasil dari aplikasi sistem pendukung keputusan pegawai yang lulus seleksi secara terurut sesuai perankingan terpilihnya menjadi alternatif terbaik pelamar yang berhak diterima[7]. Pada penelitain ini menggunakan kriteria kedisiplinan saja.

Penelitian yang dilakukan oleh Okkita Rizan dkk berjudul "SAW Method in Supporting the Process of Admission of New Junior High School Students" yang menjelaskan bahwa metode yang digunakan dalam penelitian tersebut adalah SAW (Simple Additive Weighting) dengan kriteria yang diambil Bahasa Indonesia, nilai matematika, nilai IPA, jumlah sertifikat lomba tingkat kabupaten, sertifikat lomba tingkat provinsi, sertifikat lomba tingkat nasional dan zonasi. Hasil penelitian dari 4 sampel siswa yang diambil terdapat 1 siswa yang memiliki nilai tertinggi yaitu siswa $\mathrm{C}$ dengan nilai 0,8 dan siswa dengan nilai 0,8 nilai terendah adalah siswa A dengan nilai 0,35 [8]. Pada penelitian ini menggunakan kriteria yang berbeda yaitu tanggungjawab, pendidikan terakhir, jenjang kepangkatan, kedisiplinan, komunikasi dan masa kerja

Penelitian yang dilakukan oleh Fitri dkk dengan judul "Sistem Pendukung Keputusan Rekrutmen Pegawai Btm Amanah Bangunrejo Menggunakan Metode Simple Additive Weighting (SAW)" menjelaskan bahwa penelitian ini meneliti tentang rekrutmen pegawai dengan sistem pendukung keputusan model Multiple Attribute Decision Making (MADM) dengan metode Simple Additive Weighting ( $S A W)$ dengan beberapa kriteria Kategori Jasmani (C1), Kepribadian (C2), 
Pengalaman Kerja (C3), Usia (C4), Pendidikan (C5), dan Agama (C6) dan terdapat 5 sample yang digunakan. Hasil penelitian dari hasil proses perhitungan bahwa $\mathrm{V} 1=0.89$ yang merupakan calon karyawan bernama Andin mendapat nilai sangat tinggi sedangkan V2= 0.84 yang merupakan calon karyawan bernama bintang mendapat nilai rendah dan yang mendapat nilai sangat rendah yaitu V5 $=0.79$ yang merupakan calon karyawan bernama Doni[9]. Pada penelitian ini hanya kriteria pendidikan yang sama.

Penelitian yang dilakukan oleh Gunawan dkk dengan judul "Pemilihan Kandidat Kepala Divisi Yayasan Airlangga Balikpapan dengan Metode Topsis" menjelaskan bahwa penelitian ini menggunakan metode Topsis dengan kejelasan program, relavansi hasil dengan kegiatan strategi, realisasi target, efektifitas dan komunikasi, tingkat keyakinan terhadap program kerja, kerjasama serta logikal thingking. Hasil proses perhitungan sebagai alternatif kandidat yang terpilih yaitu NK2 dengan nilai 0,9026 sebagai nilai tertinggi dan NK1 dengan nilai 0,4686 sebagai nilai terendah. Kepala Divisi yang terpilih dengan skor nilai tertinggi[10]. Pada penelitian ini menggunakan metode SAW.

Penelitian yang dilakukan oleh Abdullah dkk dengan judul "Sistem Pendukung Keputusan Pemilihan Kepala Bagian Distribusi Pada PDAM Tirtauli Pematangsiantar dengan Menggunakan Metode SAW" menyimpulkan bahwa untuk menentukan kepala distribusi dengan memiliki kualifikasi terbaik secara objektif dan sistematis. kriteria yang digunakan tanggung jawab, dorongan prestasi, kedisiplinan, komunikatif dan masa kerja. Dari sample 5 calon yang telah direkomendasikan, maka diperoleh urutan alternatifnya ialah B5/V5 =Darwin.S Harahap, B2/V2 = Maryono, B3/V3 =Jackson Hutajulu, B4/V4 =Rahmad Sihombing, dan B1/V1 = Budi Noprenda Nasution. Kandidat dengan nilai tertinggi yang terpilih menjadi kepala distribusi[11]. Pada penelitian ini menggunakan 4 sample dan 6 kriteria tanggungjawab, pendidikan terakhir, jenjang kepangkatan, kedisiplinan, komunikasi dan masa kerja.

Penelitian yang dilakukan oleh okkita dkk yang berjudul "Pemilihan Calon Ketua Badan Eksekutif Mahasiswa dengan Menerapkan FMADM (Fuzzy Multiple Attribute Decisioan Making)" dengan menerangkan bahwa ada 4 kriteria yaitu prestasi non akademik, visi dan misi, prestasi dan LDK dalam memilih ketua BEM. Hasil penelitian dengan 4 kandidat calon ketua Badan Eksekutif Mahasiswa (BEM) yang telah diurutkan berdasarkan nilai vector $\mathrm{V}$ terbesar adalah : Bayu dengan nilai V8 $=0.98$, Ade Tri Nia Putri dengan nilai V10 $=0.79$, Indah Rizky Septiani dengan nilai V6 $=0.715$ dan Endang Yosfika Utami dengan nilai V4=0.6975. Berdasarkan hasil penelitian, maka didapat ketua BEM yang terpilih dengan nilai terbesar[12]. Pada penelitian ini menggunakan metode SAW dengan kriteria yang berbeda.

\section{RESEARCH METHOD}

Metode SAW adalah metode penjumlahan bobot. Konsep metode SAW dengan mencari semua atribut dengan melakukan penjumlahan terbobot dari rating kinerja pada setiap alternatif[13]. Penggunaan metode SAW dikarenakan metode ini dapat menentukan alternatif pilihan yang terbaik sehingga membantu dalam mengambil keputusan secara cepat dan tepat. Proses normalisasi matrik keputusan (X) ke suatu skala yang dapat diperbandingkan dengan semua rating alternatif yang ada. Berikut formula dalam melakukan normalisasi dalam metode SAW:

$$
r_{i j}= \begin{cases}\frac{X_{i j}}{\operatorname{Max} X_{i j}} & \longrightarrow \\ i & \mathrm{j} \text { atribut benefit } \\ \frac{\operatorname{Min} X_{i j}}{X_{i j}} \longrightarrow & \mathrm{J} \text { atribut cost }\end{cases}
$$

Keterangan :

$r i j=$ Nilai rating kerja ternormalisasi

$X i j=$ Nilai atribut yang dimiliki setiap alternatif

Maxi $=$ Nilai terbesar

Mini $=$ Nilai terkecil

Benefit $=$ Jika nilai terbesar $\mathrm{B}$ dalah terbaik

Cost $=$ Jika nilai terkecil $\mathrm{B}$ dalah terbaik

Dimana $r i j$ adalah rating kinerja ternormalisasi dari alternatif $B i$ pada atribut $C j ; \mathrm{i}=1,2, \mathrm{~m}$ dan $\mathrm{j}=1,2, . ., \mathrm{n}$.

Nilai prefensi untuk setiap alternatif ( $V i$ diberikan sebagai:

$$
V_{i}=\sum_{j=1}^{n} W_{j} r_{i j}
$$

Keterangan :

$V i j=$ Rangking untuk setiap alternatif

$W j=$ Nilai bobot dari setiap kriteria

$r i j=$ Nilai rating kerja ternormalisasi

Nilai $V i$ yang lebih besar mengindikasikan bahwa alternatif $B i$ lebih terpilih.

Berikut tahap-tahap dalam metode SAW (Simple Additive Weighting) yang digunakan dalam penelitian ini dimulai dari memasukkan data alternatif, menentukan bobot dan kriteria, membuat matriks keputusan, melakukan pemeringkatan matriks keputusan dengan bobot kriteria sampai membuat preferensi setiap kriteria yang dapat dilihat pada gambar 1 seperti dibawah ini : 


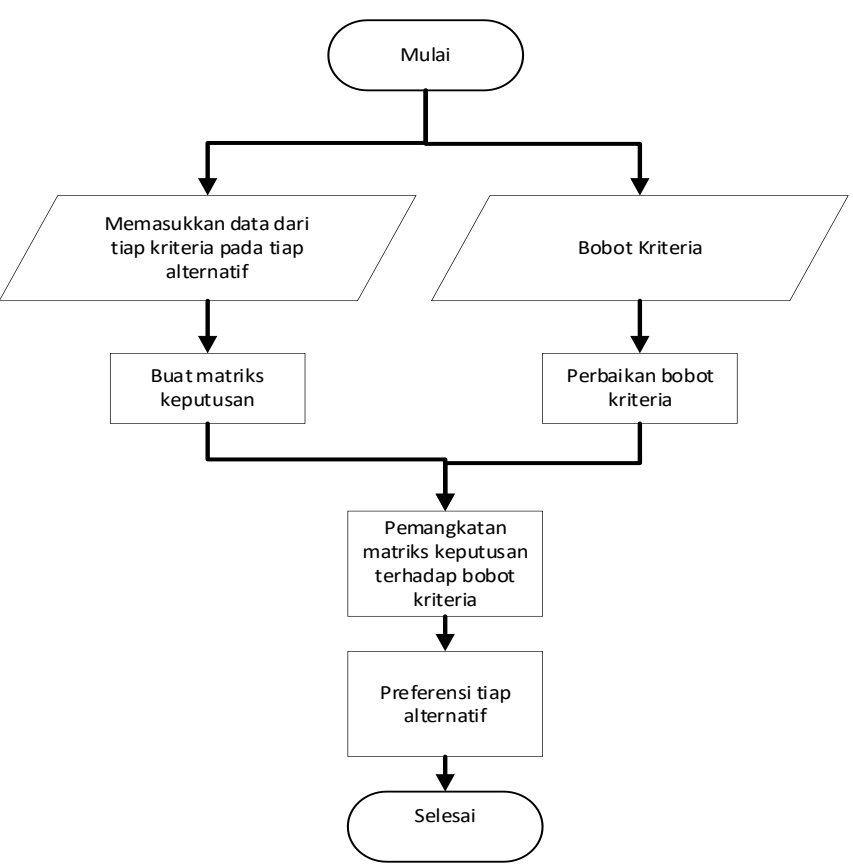

Gambar .1. Tahapan Metode SAW

Berikut algoritma yang dipakai dalam menyelesaikan masalah :

1. Memberikan nilai setiap alternatif pada setiap kriteria yang sudah ditentukan

2. Memberikan nilai bobot

3. Melakukan normalisasi matriks dengan cara menghitung nilai rating kinerja ternormalisasi dari alternatif berdasarkan persamaan yang disesuaikan dengan jenis atribut.

4. Melakukan proses perangkingan dengan cara mengalikan matriks normalisasi dengan nilai bobot.

5. Menentukan nilai preferensi untuk setiap alternatif dengan cara menjumlahkan perkalian antara nilai bobot dan matriks normalisasi.

\section{RESULT AND DISCUSSION}

\section{A. Pemecahan Masalah Metode SAW}

Penelitian ini peneliti akan melakukan proses penyeleksian kepala biro dengan menggunakan metode SAW (Simple Additive Weighting). Dalam pemilihan kepala biro, peneliti sudah menentukan kriteria-kriteria dan bobot yang sudah disepakati oleh pihak top management. Kriteria dan bobot yang sudah ditentukan akan dijadikan dasar dalam perhitungan untuk menghasilkan alternatif terbaik. Penentuan kriteria dan bobot diambil dari data kriteria salah satu perusahaan yang menjadi sample dalam penyusunan penelitian ini yang sudah ditentukan oleh top manajemen perusahaan. Dari data tersebut dibuatkan penjabaran kriteria masing-masing.

\section{B. Kriteria dan Bobot}

Adapun kriteria-kriteria yang ditentukan beserta bobotnya adalah sebagai berikut :
TABEL 1. KRITERIA

\begin{tabular}{ccc}
\hline Kriteria & Keterangan & Bobot \\
\hline C1 & Tanggung Jawab & $30 \%$ \\
\hline C2 & Pendidikan Terakhir & $20 \%$ \\
\hline C3 & Jenjang Kepangkatan & $15 \%$ \\
\hline C4 & Kedisiplinan & $15 \%$ \\
\hline C5 & Komunikasi & $10 \%$ \\
\hline C6 & Masa Kerja & $10 \%$ \\
\hline
\end{tabular}

Berdasarkan masing-masing kriteria diatas akan ditentukan bobotnya. Data bobot dapat dilihat pada tabel dibawah ini :

TABEL 2. BOBOT

\begin{tabular}{cc}
\hline Keterangan & Bobot \\
\hline Sangat Tinggi & 1 \\
\hline Tinggi & 0,75 \\
\hline Sedang & 0,50 \\
\hline Rendah & 0,25 \\
\hline Sangat Rendah & 0 \\
\hline
\end{tabular}

\section{Perhitungan Metode SAW}

Dalam perhitungan metode SAW, akan dilakukan langkahlangkah sebagai berikut :

1. Memberikan nilai setiap alternatif dari setiap kriteria yang sudah ditentukan

a. Tanggung Jawab

Adapun bobot yang ditentukan untuk untuk kriteria tanggung jawab dapat dilihat pada tabel dibawah ini:

TABEL 3. BOBOT TANGGUNG JAWAB

\begin{tabular}{cc}
\hline Keterangan & Bobot \\
\hline Sangat Baik & 1 \\
\hline Baik & 0,75 \\
\hline Cukup & 0,50 \\
\hline Kurang & 0,25 \\
\hline Sangat Kurang & 0 \\
\hline
\end{tabular}

\section{b. Pendidikan Terakhir}

Adapun bobot yang ditentukan untuk untuk kriteria pendidikan terakhir dapat dilihat pada tabel dibawah ini: TABEL 4. BOBOT PENDIDIKAN TERAKHIR

\begin{tabular}{cc}
\hline Keterangan & Bobot \\
\hline S2 & 1 \\
\hline S1 & 0,75 \\
\hline SMA & 0,50 \\
\hline SMP & 0,25 \\
\hline SD & 0 \\
\hline
\end{tabular}

c. Jenjang Kepangkatan

Adapun bobot yang ditentukan untuk untuk kriteria jenjang kepangkatan dapat dilihat pada tabel dibawah ini:

TABEL 5. BOBOT JENJANG KEPANGKATAN

\begin{tabular}{cc}
\hline Keterangan & Bobot \\
\hline Guru Besar & 1 \\
\hline Lektor Kepala & 0,75 \\
\hline Lektor 300 & 0,50 \\
\hline Lektor 200 & 0,25 \\
\hline Asisten Ahli & 0
\end{tabular}




\section{d. Kedisiplinan}

Adapun bobot yang ditentukan untuk untuk kriteria kedisiplinan dapat dilihat pada tabel dibawah ini:

TABEL 6. BOBOT KEDISIPLINAN

\begin{tabular}{cc}
\hline Keterangan & Bobot \\
\hline Sangat Baik & 1 \\
\hline Baik & 0,75 \\
\hline Cukup & 0,50 \\
\hline Kurang & 0,25 \\
\hline Sangat Kurang & 0 \\
\hline
\end{tabular}

e. Komunikasi

Adapun bobot yang ditentukan untuk untuk kriteria komunikasi dapat dilihat pada tabel dibawah ini:

TABEL 7. BOBOT KOMUNIKASI

\begin{tabular}{cc}
\hline Keterangan & Bobot \\
\hline Sangat Baik & 1 \\
\hline Baik & 0,75 \\
\hline Cukup & 0,50 \\
\hline Kurang & 0,25 \\
\hline Sangat Kurang & 0 \\
\hline
\end{tabular}

\section{f. Masa Kerja}

Adapun bobot yang ditentukan untuk untuk kriteria masa kerja dapat dilihat pada tabel dibawah ini:

TABEL 8. BOBOT MASA KERJA

\begin{tabular}{cc}
\hline Keterangan & Bobot \\
\hline$<2$ Tahun & 0 \\
\hline $2-4$ Tahun & 0,25 \\
\hline $5-10$ Tahun & 0,50 \\
\hline $10-15$ Tahun & 0,75 \\
\hline$>15$ Tahun & 1 \\
\hline
\end{tabular}

Terdapat 4 orang sample yang akan mengikuti pemilihan kepala biro pada penelitian ini berdasarkan nilai kriteria yang sudah ditentukan. Tetapi dari 4 kandidat yang akan dipilih menjadi kepala biro hanya satu orang. Berikut 4 orang kandidat (alternatif) yaitu sebagai berikut:

a. Kandidat 1 (Alternative 1/A1)

b. Kandidat 2 (Alternative 2/A2)

c. Kandidat 3 (Alternative 3/A3)

d. Kandidat 4 (Alternative 4/A4)

Berdasarkan nilai bobot per alternatif, maka dibuatkan tabel rating kecocokan dari setiap alternatif pada setiap kriteria kemudian disesuaikan dengan nilai pembobotan sehingga diperoleh hasil sebagai berikut:

TABEL 9. RATING KECOCOKAN DARI SETIAP ALTERNATIF PADA SETIAP KRITERIA

\begin{tabular}{lllllll}
\hline Alternative & \multicolumn{6}{c}{ Criteria } \\
\cline { 2 - 7 } & $\boldsymbol{C 1}$ & $\boldsymbol{C 2}$ & $\boldsymbol{C 3}$ & $\boldsymbol{C 4}$ & $\boldsymbol{C 5}$ & $\boldsymbol{C 6}$ \\
\hline $\begin{array}{l}\text { Kandidat 1 } \\
\text { (A1) }\end{array}$ & Baik & S2 & L300 & $\begin{array}{l}\text { Sangat } \\
\text { Baik }\end{array}$ & $\begin{array}{l}\text { Sangat } \\
\text { Baik }\end{array}$ & $>15$ \\
\hline Kandidat 2 & Sangat & S2 & L200 & Baik & Sangat & $10-15$ \\
\hline
\end{tabular}

\begin{tabular}{|c|c|c|c|c|c|}
\hline (A2) & Baik & & & Baik & \\
\hline $\begin{array}{l}\text { Kandidat } 3 \\
\text { (A3) }\end{array}$ & $\begin{array}{ll}\text { Sangat } & \text { S2 } \\
\text { Baik } & \end{array}$ & L200 & Baik & Baik & $10-15$ \\
\hline $\begin{array}{l}\text { Kandidat } 4 \\
\text { (A4) }\end{array}$ & $\begin{array}{ll}\text { Sangat } & \text { S2 } \\
\text { Baik } & \end{array}$ & L300 & $\begin{array}{l}\text { Sangat } \\
\text { Baik }\end{array}$ & Baik & $>15$ \\
\hline
\end{tabular}

Dari data rating kecocokan diatas, maka kemudian menentukan nilai matrix $\mathrm{X}$. adapaun matrik $\mathrm{X}$ dapat dilihat dibawah ini :

$$
\mathrm{X}=\left[\begin{array}{llcccc}
\mathrm{C} 1 & \mathrm{C} 2 & \mathrm{C} 3 & \mathrm{C} 4 & \mathrm{C} 5 & \mathrm{C} 6 \\
0,75 & 1 & 0,50 & 1 & 1 & 1 \\
1 & 1 & 0,25 & 0,75 & 1 & 0,75 \\
1 & 1 & 0,25 & 0,75 & 0,75 & 0,75 \\
1 & 1 & 0,50 & 1 & 0,75 & 1
\end{array}\right]
$$

\section{Menormalisasikan Matrik X menjadi Matrik $R$}

Dari data hasil penentuan nilai matrik X, maka kemudian menentukan nilai matrix $\mathrm{R}$. adapaun matrik $\mathrm{R}$ dapat dihitung menggunakan rumus dibawah ini dan hasilnya dapat dilihat dibawah ini :

$$
r i j=\frac{x i j}{\operatorname{Max}(x i j)}
$$

Kemudian membuat matriks normalisasi didapatkan hasil normalisasi dibuat dalam matrik dibawah ini :

$$
\mathrm{R}=\left[\begin{array}{llllll}
0,75 & 1 & 1 & 1 & 1 & 1 \\
1 & 1 & 0,5 & 0,75 & 1 & 0,75 \\
1 & 1 & 0,5 & 0,75 & 0,75 & 0,75 \\
1 & 1 & 1 & 1 & 0,75 & 1
\end{array}\right]
$$

\section{Memberikan Nilai Bobot $(W)$}

Setelah menentukan nilai matrik $\mathrm{R}$, maka langkah selanjutnya menentukan nilai bobot setiap perangkingan. Adapun nilai bobot perankingan dapat dilihat dibawah ini :

$$
\text { Weight Vector }(W)=\left\{\begin{array}{llllll}
0,30 & 0,20 & 0,15 & 0,15 & 0,10 & 1,10
\end{array}\right\}
$$

\section{Melakukan Proses Perangkingan}

Proses selanjutnya adalah membuat peringkat alternatif (Vi). Untuk mendapatkan proses pemeringkatan, yaitu dengan mengalikan vektor bobot (W) dengan matriks ternormalisasi (R). Hasil yang diperoleh dari perkalian vektor bobot dengan matriks ternormalisasi (R) dihitung dengan menggunakan rumus sebagai berikut:

$$
\mathrm{Vi}=\sum W j \cdot R i j
$$

Berdasarkan hasil perhitungan peringkat setiap alternatif diatas, maka diperoleh nilai masing-masing kandidat yang dapat dilihat pada tabel dibawah ini: 
TABEL 10. HASIL PERANGKINGAN ALTERNATIF

\begin{tabular}{lc}
\hline \multicolumn{1}{c}{ OPTIONAL ALTERNATIVE } & SKOR \\
\hline Kandidat 1 (V1) & 0,925 \\
\hline Kandidat 2 (V2) & 0,8625 \\
\hline Kandidat 3 (V3) & 0,8375 \\
\hline Kandidat 4 (V4) & 0,975 \\
\hline
\end{tabular}

Dari tabel jumlah skor diatas, maka dapat dilihat bahwa antara V1 sampai dengan V4 dan berikut adalah hasil rangking dari kandidat/ alternatif sebagai Kepala Bagian Biro adalah sebagai berikut:

TABEL 11. HASIL PERANGKINGAN ALTERNATIF

\begin{tabular}{lcc}
\hline OPTIONAL ALTERNATIVE & VALUE & RATING \\
\hline Kandidat 4 (V4) & 0,975 & 1 \\
\hline Kandidat 1 (V1) & 0,925 & 2 \\
\hline Kandidat 2 (V2) & 0,8625 & 3 \\
\hline Kandidat 3 (V3) & 0,8375 & 4
\end{tabular}

\section{CONCLUSION}

Berdasarkan hasil penelitian maka dapat disimpulkan bahwa metode SAW (Simple Additive Weighting) dapat memberikan hasil pemilihan kepala biro dengan cara menghitung nilai preferensi (Vi) tertinggi pada masing-masing kandidat atau alternatif. Dari sample yang telah disedikan, maka diperolah calon kandidat terpilih. Nilai tertinggi akan dijadikan prioritas pertama sebagai kepala biro. Dari Hasil penelitian yang telah dilakukan, maka diperoleh skor dari urutan setiap alternatif yaitu kandidat 4/V4, kandidat $1 / \mathrm{V} 1$, kandidat 2/V2 dan kandidat 3/V3.

\section{REFERENCES}

[1] S. H. Kusumadewi, "Fuzzy Multi-Attribute Decision Making (Fuzzy MADM)," Graha Ilmu Yogyakarta, 2006.

[2] Kusrini, "Konsep Dan Aplikasi Sistem Pendukung Keputusan," Penerbit Andi. 2007.

[3] S. M. Sumarno and J. M. Harahap, "Sistem Pendukung Keputusan Dalam Menentukan Pemilihan Posisi Kepala Unit (Kanit) Ppa Dengan Metode Weight Product," JUST IT J. Sist. Informasi, Teknol. Inf. dan Komput., vol. 11, no. 1, p. 37, 2020, doi: 10.24853/justit.11.1.37-44.

[4] O. Rizan, "Penerapan Metode SAW ( Simple Additive Weighting ) dalam Pemilihan Dosen Favorit Berbasis Web," pp. 8-9, 2018.

[5] S. S. Sundari and Y. F. Taufik, "Pegawai Baru Dengan Menggunakan Metode Simple Additive Weighting ( Saw )," Sisfotenika, vol. Vol. 4, No, pp. 140-151, 2014.

[6] R. M. Hariyanto and Maslihah, "Sistem Pendukung
Keputusan Seleksi Pemilihan Kepala Bagian Perum Damri Surabaya," Melek IT Inf. Technol. J., vol. 3, no. 2, pp. 35-40, 2017.

[7] Y. Djamain, "Sistem Pendukung Keputusan Penerimaan Pegawai Baru Pt.Pln (Persero) Kantor Pusat Dengan Menggunakan Metode Simple Additive Weighting (Saw)," J. Tek. Inform., vol. 8, no. 1, pp. 3947, 2015, doi: 10.15408/jti.v8i1.1935.

[8] Hamidah, O. Rizan, D. Wahyuningsih, H. A. Pradana, and S. Ramadella, "SAW Method in Supporting the Process of Admission of New Junior High School Students," 2020 8th Int. Conf. Cyber IT Serv. Manag. CITSM 2020, 2020, doi: 10.1109/CITSM50537.2020.9268874.

[9] F. Saraswati and Y. Fitrian, "BTM AMANAH BANGUNREJO MENGGUNAKAN METODE SIMPLE ADDITIVE WEIGHTING ( SAW )," pp. 211-219.

[10] T. Informatika and M. Topsis, "Candidate Election Head Division," 2018.

[11] A. Ahmad, S. R. Andani, P. Studi, M. Informatika, and S. P. Keputusan, "METODE SAW," vol. 2, 2018.

[12] Hamidah and O. Rizan, "Pemilihan Calon Ketua Badan Eksekutif Mahasiswa Dengan Menerapkan FMADM (Fuzzy Multiple Attribute Decision Making)," Telematika, vol. 10, no. 1, pp. 75-90, 2017, [Online]. Available:

http://ejournal.amikompurwokerto.ac.id/index.php/tele matika/article/view/488.

[13] H. Hengki, O. Rizan, B. Isnanto, H. Hamidah, and ... "Optimasi Pemilihan Model Pembelajaran Berbasis SCL Menggunakan Saw Method Pada Perguruan Tinggi XYZ," Jutis (Jurnal Tek. ..., vol. 7, no. 1, pp. 22-28, 2020, [Online]. Available: http://ejournal.unis.ac.id/index.php/jutis/article/view/1 43.

[14] Martono, "Perancangan Aplikasi Human Resource Information System (HRIS) Berbasis Java," J. V-Tech (Vision Technol., 2019.

[15] D. Pibriana, "Penggunaan Metode Simple Additive Weighting (SAW) dalam Pengambilan Keputusan Rekrutmen Karyawan Pada PT. ABC," Techno.Com, vol. 19, no. 1, pp. 45-55, 2020, doi: 10.33633/tc.v19i1.2771. 